\title{
DE LOGE TE DJAMBI IN HET JAAR 1707.
}

(Met één kaart en vier teekeningen).

DOOR

J. W. J. WELLAN.

In het Algemeen Rijksarchief te 's-Gravenhage troffen wij drie teekeningen aan van de loge te Djambi, gedateerd 1707 , welke in den catalogus vermeld onder de nummers $1136,1136^{a}$ en 1137 , de navolgende omschrijving dragen:

„1136 : Platte grond van 's-Comps. Logie 1707;

„1136": Platte grond van de Pagger, die om de Logie leyt. Schaal van 6 Rijnl. Roeden $=150$ streepen. Groot $0,51-0,745 \mathrm{El}$;

„1137 : Afbeelding van de gebouwen binnen de Logie, zoo van voren als van agteren. Opgemeten 18 Oct. 1707. Groot $0,75-0,51 \mathrm{El}$ ".

Zijn wij over het algemeen niet verwend met afbeeldingen van onze vroegere nederzettingen in de(n) Oost, wat Djambi betreft zijn dit - voor zoover bekend - de eenige.

Zou er op grond daarvan reeds aanleiding bestaan ze aan de vergetelheid te ontrukken, het feit, dat zij ons een blik gunnen in het ontwikkelingspeil van de bouw- en versterkingskunst dier dagen, is mede een motief om die vergeelde platen hier te publiceeren ${ }^{1}$ ) en te bespreken.

Aan eene bespreking daarvan behoort echter vooraf te gaan eene beschrijving van den stand van zaken te Djambi in het jaar 1707 .

$\mathrm{Nu}$ wil echter het ongeluk, dat er over de oude geschiedenis van Djambi niet heel veel bekend is, en dat, wat er nog over geschreven werd - na vergelijking met de origineele bescheiden in het Algemeen Rijksarchief te 's-Gravenhage aanwezig - gebleken is in vele opzichten niet met de werkelijkheid overeen te stemmen.

De eenige bron, die hierover nog de uitvoerigste inlichtingen geeft,

1) Met uitzondering van de teekening bedoeld sub 1136", die daarvoor niet belangrijk genoeg wordt geacht. De op die teekening aangegeven noten worden echter wèl behandeld. 
is de nieuwe Encyclopaedie van Nederlandsch-Indië ${ }^{1}$ ), waarin wij het navolgende lezen:

„Vooral met het doel om zich in den handel meer onafhankelijk te maken van Bantam, richtte de O. I. C. in 1616 te Djambi een kantoor op, dat zij, met korte onderbreking in 1643, en van 20 September 1679 tot Mei 1680, tot 1696 handhaafde, en dat belangrijk was om den handel in peper en verschillende boschproducten. In 1643 werd het eerste contract met den Vorst gesloten; in 1687 kon de O. I. C. hem aan zich verplichten door zijn verzoek om hulp een aanval van den Radja van Djohor en den Sultan van Palembang af te wenden.

Niet altijd echter was de verhouding zoo vriendschappelijk; dat blijkt o.a. uit den moord op het hoofd der factorij in 1690 . De toenmalige vorst Ingalaga, de eerste, die den Sultans titel voerde, werd gevangen genomen en zijn zoon Kijai Gedé op den troon geplaatst. Onder Kijai Gedés opvolger in 1696 werd de verhouding met de O. I. C. zóó gespannen, dat het kantoor werd opgebroken.

In 1707 gaf de Sultan blijk de relaties weer te willen aanknoopen door een gezantschap aan den G.G. Het kantoor werd hersteld en te Moeara Koempih een sterkte opgericht. Deze sterkte werd in 1724, vermoedelijk ten gevolge van een opstand tegen de Nederlanders, weer verlaten. Voor zoover bekend is, kwamen zij er niet vóór 1833 terug. Omtrent hetgeen tusschen 1724 en 1833 gebeurd is in Djambi ontbreken stellige berichten, enz.".

Uit eene vergelijking van de - aan den voet van het artikel vermelde - bronnen met de origineele, blijkt, dat de bewerker van dit gedeelte der Encyclopaedie hoofdzakelijk heeft gebruik gemaakt van Prof. Veth's beschrijving der geschiedenis van Djambi, voorkomende in de inleiding van het werk over Sumatra's Westkust van Ridder de Stuers ${ }^{2}$ ), terwijl deze Hoogleeraar weer zijne gegevens ontleende aan ,eenige langwijlige legenden omtrent den oorsprong en de opkomst van Djambi" ${ }^{3}$ ), en het bekende werk van Valen-

1) 2e Druk, I, 1917, p. 610. Insgelijks 1e druk, I, p. 453.

2) „De vestiging en uitbreiding der Nederlanders ter Westkust van Sumatra”, door den Generaal-Majoor H. J. J. L. Ridder de Stuers, oud-Resident ter Westkust van Sumatra, enz. Uitgegeven door P. J. Veth, Hoogleeraar te Amsterdam. I, Amsterdam, 1849, p. XXXIV e.v. Aldus ook in Dr. P. J. Veth, „De geschiedenis van Sumatra”. De Gids, 13e Jrg., N. S., 2e Jrg., II, 1849, p. $572-573$.

3) Idem, p. XXXV en noot 1. 
tijn ${ }^{1}$ ). Maar, waar Prof. Veth zelf zegt, dat die legenden „weinig opmerkelijks leeren" ${ }^{2}$ ), en Jhr. Mr. J. K. J. de Jonge den ouden Valentijn een brevet van onbekwaamheid als geschiedschrijver geeft $^{3}$ ), is het - zelfs op gevaar af dit opstel topzwaar te maken gewenscht, vooraf eenige feiten recht te zetten.

Met uitzondering van den verkeerden datum van eerste vestiging in Djambi, die, zooals wij reeds uit de door de eerste Residenten, Abraham Sterck en Andries Soury, ingediende rapporten weten. niet 1616 maar 1615 is ${ }^{4}$ ), zijn de andere gegevens, namelijk die, over de onderbrekingen van ons verblijf aldaar in 1643 en van 20 September 1679 tot 30 Mei 1680, juist.

Het eerstbedoelde feit werd, naar of ficieele documenten vastgelegd door $\mathrm{Mr}$. Heeres ${ }^{5}$ ), de beide andere data volgen o.a. uit de aanteekeningen in de Dagh-Registers $\left.{ }^{6}\right)$. Maar wat er verder verteld wordt over de gebeurtenissen nà 1690 , namelijk over den politieken moord op het hoofd der factorij, en als gevolg daarvan de verbanning van den Vorst van Djambi, Ingalaga, zoomede de gespannen verhouding met de O. I. C. in 1696 onder Kijai Gedé's opvolger, en de opbreking van het kantoor van 1696 tot 1707 is er geheel naast.

Daarom wordt duidelijkheids- en kortheidshalve hieronder in chronologische volgorde aangegeven hoe de gebeurtenissen zich dan wèl hebben toegedragen.

Sultan Ingalaga van Djambi ${ }^{7}$ ) die - wijl hij in onmin leefde met

1) Ridder de Stuers, idem, p. XXXVI en XXXVIII. Fr. Valentijn, „Oud en Nieuw Oost Indiën, enz.", Dordrecht-Amsterdam, V, 1726.

2) Idem, p. XXXV.

3) „De opkomst van het Nederlandsch Gezag over Java, enz.” 's-Gravenhage, Amsterdam, 1875, V, p. XCI, Noot 1: „Valentijn verhaalt als ooggetuige nog vele bijzonderheden; maar een overzicht ontbreekt, bij gemis aan historischen blik, geheel".

4) J. W. J. Wellan, „Onze eerste vestiging in Djambi”. Bijdr. Kon. Inst., dl. 82, Afl. III en IV, 1926, p. 339-383.

$\left.{ }^{5}\right)$ P. A. Tiele en Mr. J. E. Heeres, „Bouwstoffen voor de geschiedenis der Nederlanders in den Indischen Archipel", 's-Gravenhage, dl. III, 1895, p. 137-139, Documenten, No. XVIII en noot 1 op p. 137.

6) Dagh-Register, gehouden int Casteel Batavia vant passerende daer ter plaetse als over geheel Nederlandts India, Jaar 1679, p. 427 en Jaar 1680, ps. 280, 387, 545, 546, 646.

7) In den „Stamboom van het Vorstenhuis (kraton) van Djambi (volgens de overlevering)", voorkomende in „Reizen en onderzoekingen der Sumatra- 
Kaart „van de Rivier van Djamby, van de Mond tot aan Djamby, schaal van 5 Duitsche mijlen $=125$ strepen” 17 eeuw.

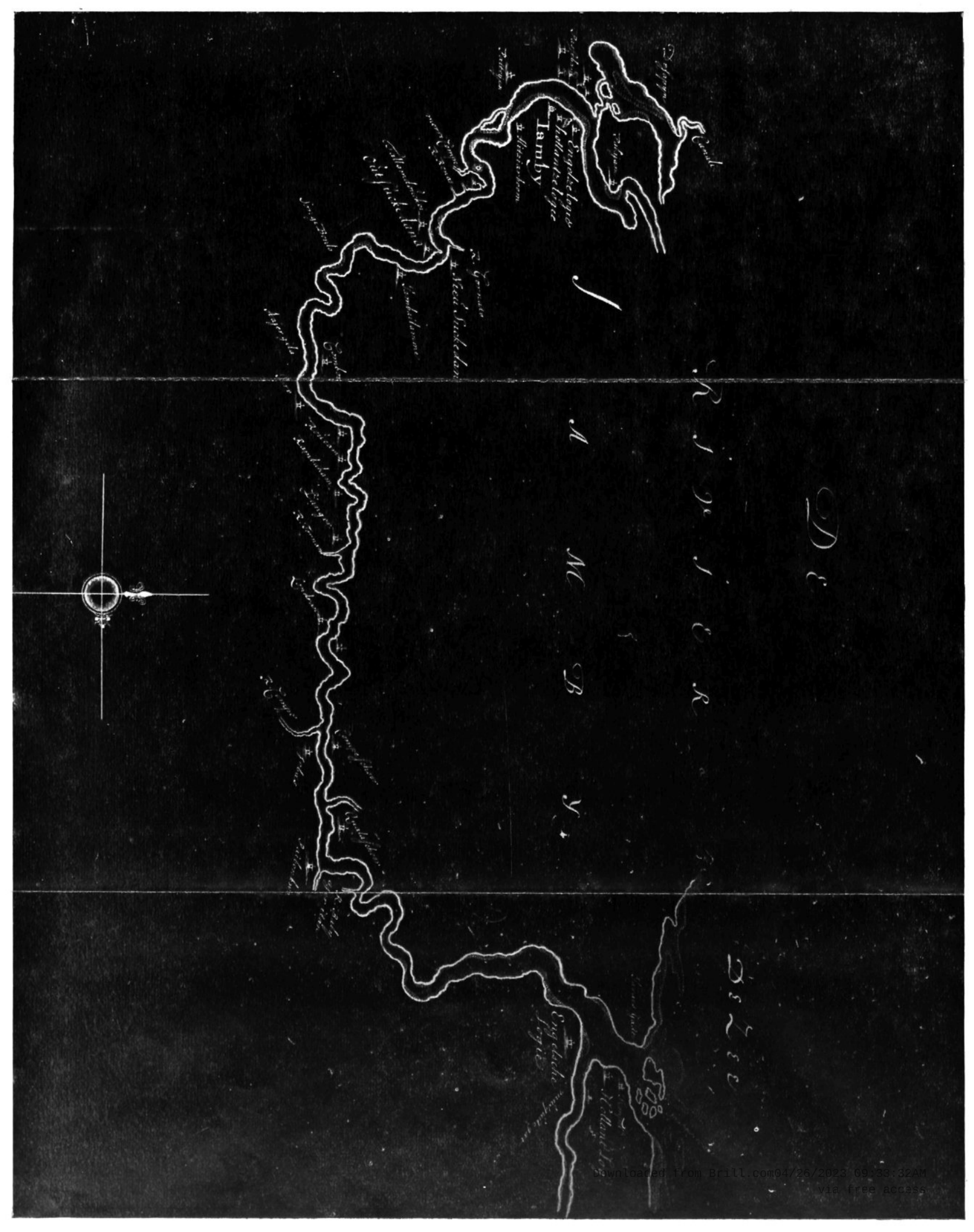


Afbeelding 1. „Platte grondt van 's Compagnies Logie op Jamby, 1707” - Kol. ^rchief, Nº. 1136.

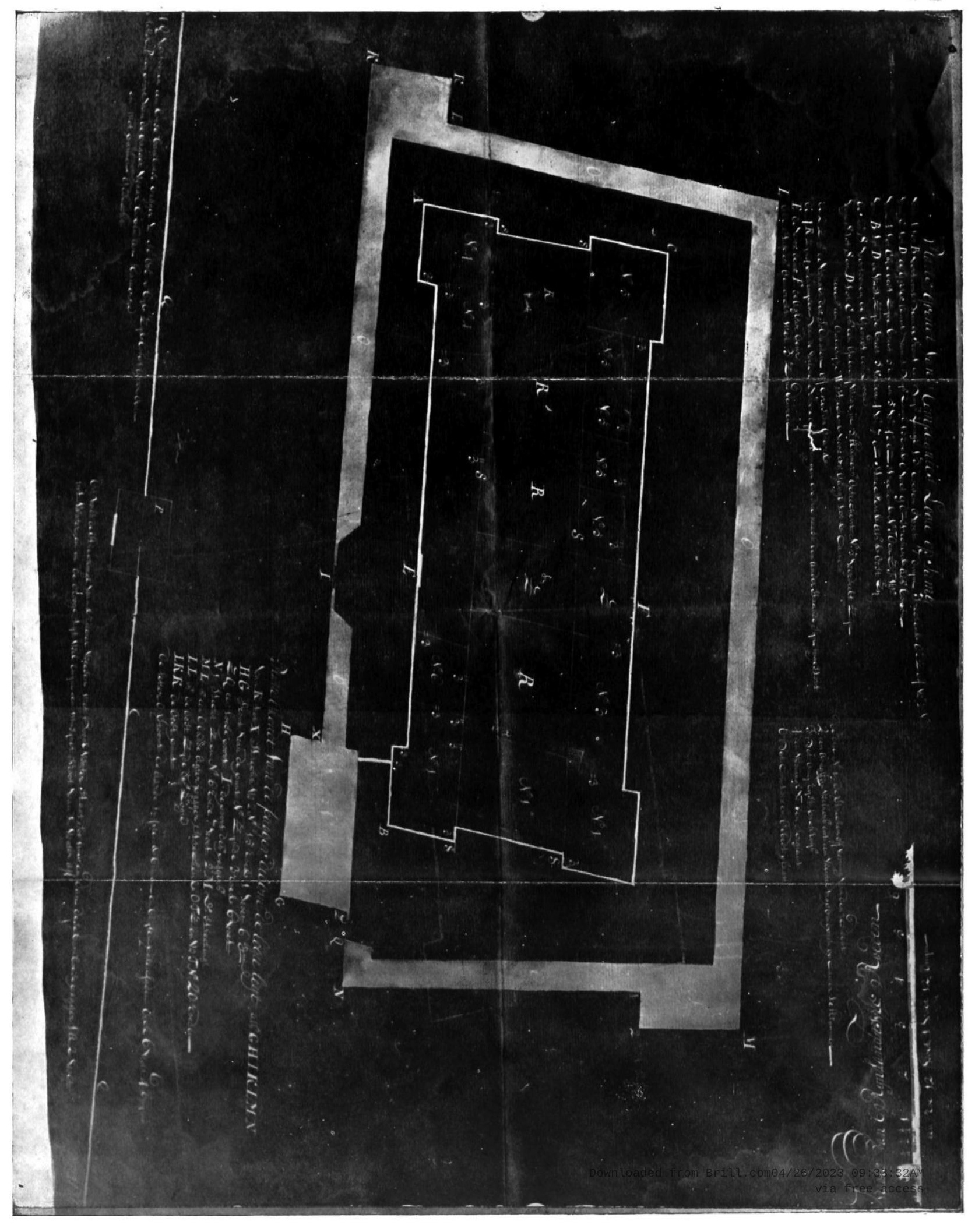




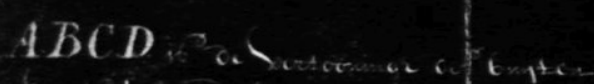

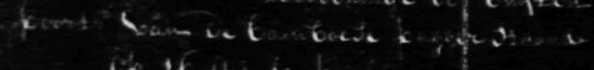

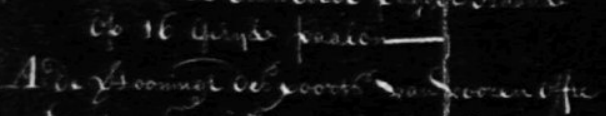

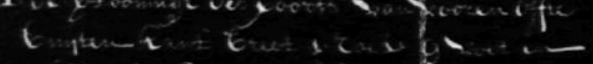

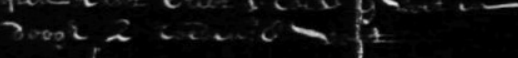

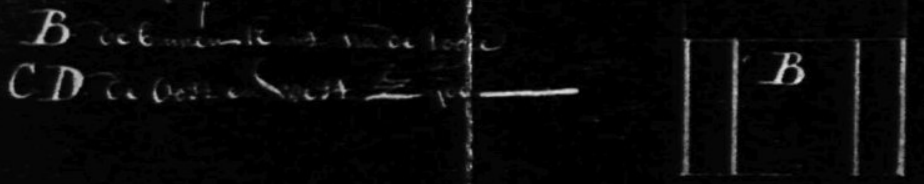

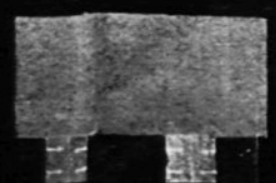

를

$|A| \mid$

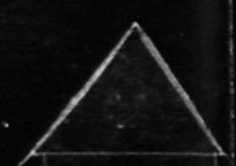

- 8

$|\mathrm{C}| \mid$

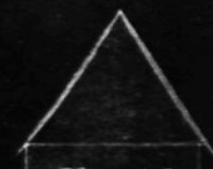

닫ㄷㅇ

$|D| \mid$

Afbeelding 2. Observatiepost boven de poort van de bamboe omheining.

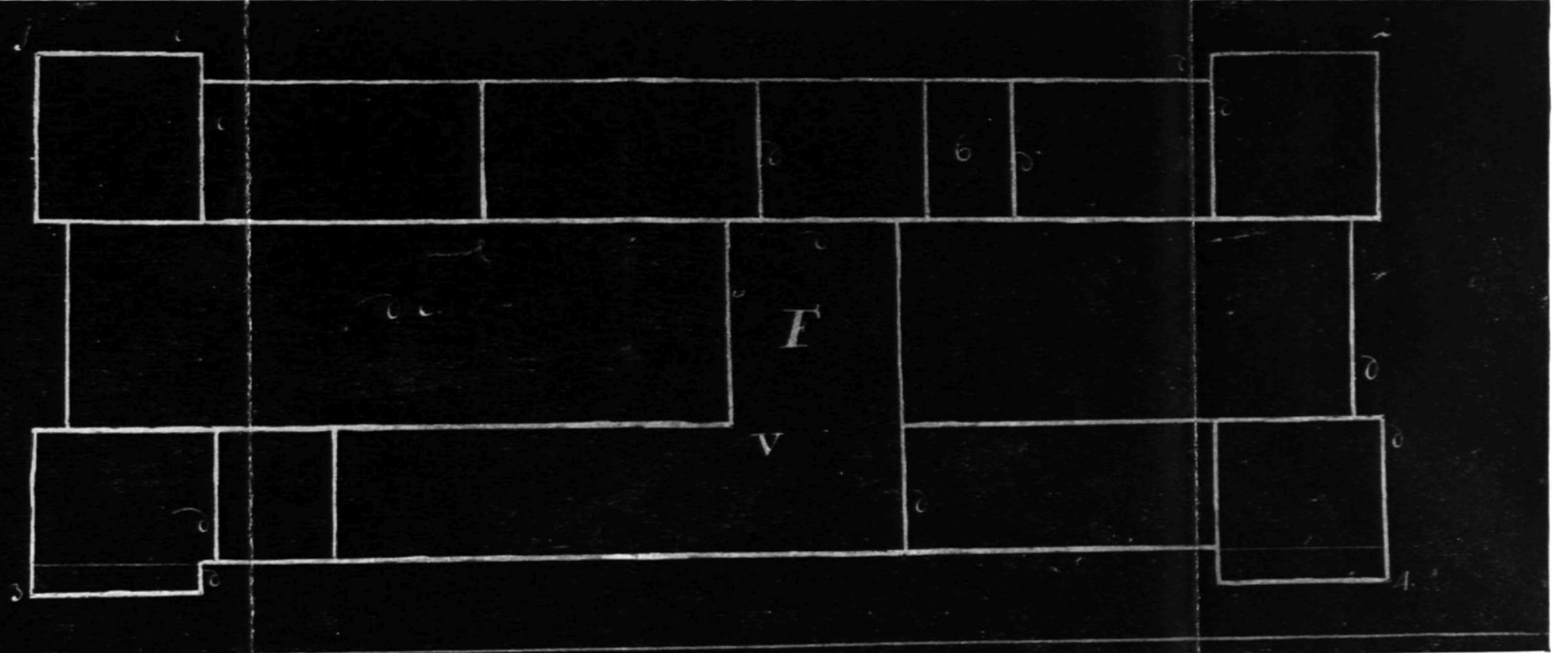

Afbeelding 3. Platte grond van het woon- tevens pakhtilisad 
Af beelding 4. Voor en zijaanzicht van het woon- tevens pakhuis.

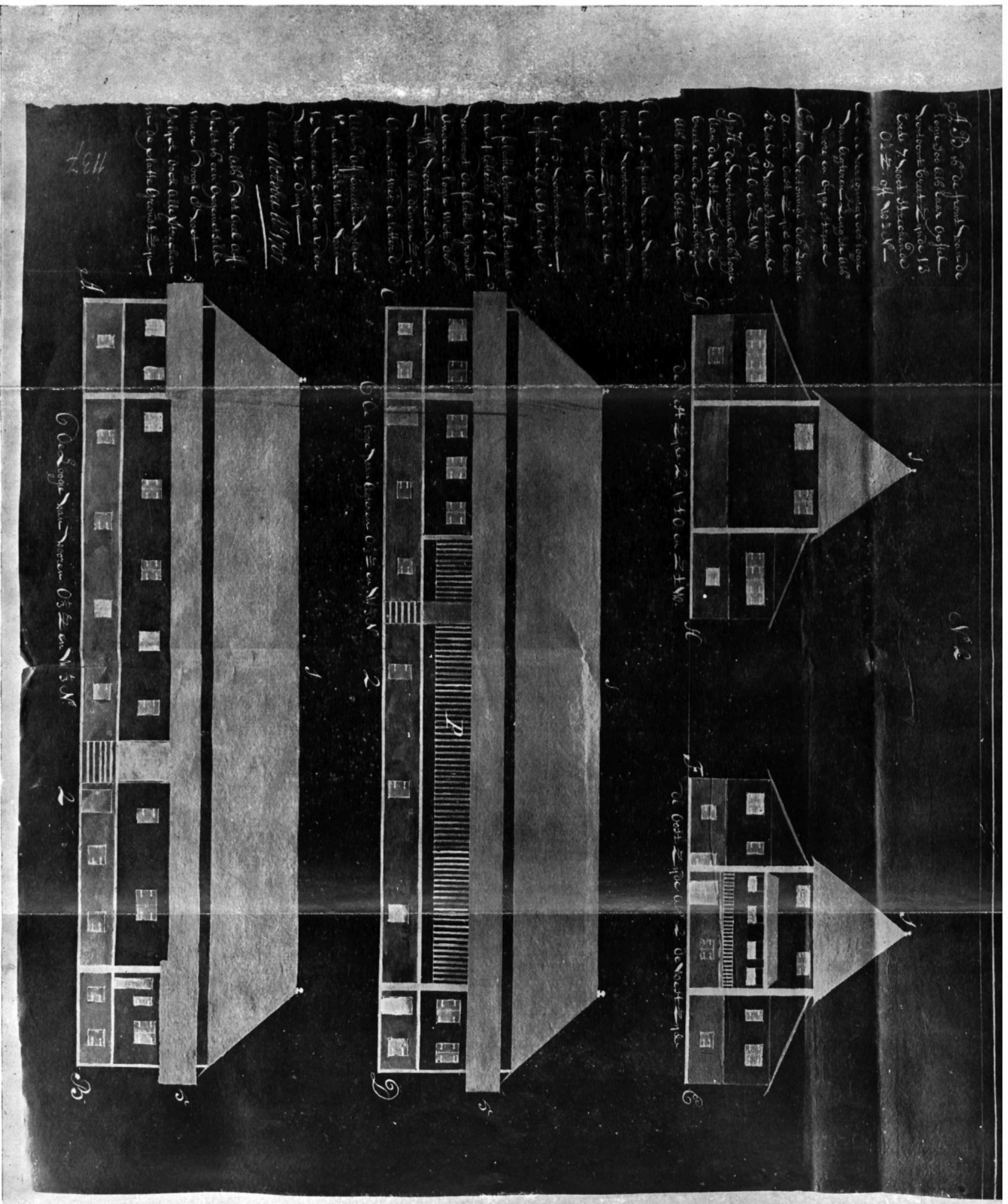


de O.I.C. en zijn oudsten zoon, den Pangeran Depati, Kijaj Gedée - al geruimen tijd in de binnenlanden vertoefde, werd blijkens de brieven van de Kooplieden te Djambi, Sybrant Swart en Cornelis Couwenhoeven, ddo. 25 Februari en 31 Maart 1688 in Maart van dat jaar ${ }^{1}$ ) met list naar de hoofdplaats gelokt, door ons gevangen genomen en naar Batavia overgebracht. De Hooge Regeering aldaar interneerde hem eerst op een schip, liggende ter reede van Batavia, later aan wal, en verbande hem ten slotte naar Banda ${ }^{2}$ ).

Zijn oudste zoon, die in 1687 reeds door de Rijksgrooten tot Sultan was verkozen en den titel had aangenomen van Sultan Kijaj Gedée, werd na Ingalaga's verbanning ook door ons als Vorst van Djambi erkend, hoewel hij in de brieven van de Hooge Regeering dikwijls nog als „Prins Regent” ${ }^{3}$ ) werd aangeduid. Eerst in 1710 volgde zijne of ficieele erkenning als Vorst van Djambi (zie verder).

De beide jongere broers van dezen, de Pangeran Ratoe, Raden Tjoelit, ook Pangeran Pringabaja geheeten, en Kijaj Singa Patih verzetten zich tegen de verheffing van Kijaj Gedée tot bestuurder van Djambi, en de verbanning van hun vader, weken naar de binnenlanden uit, en begonnen van daar uit den Prins Regent en de Com-

expeditie, uitgerust door het Aardrijkskundig Genootschap, 1877-1879, beschreven door de leden der Expeditie onder toezicht van Prof. P. J. Veth", III, „Volksheschrijving en taal door A. L. van Hasselt”, Leiden; 1882, 1e ged., tegenover p. 200, wordt hij genoemd: Soeltán-Abdoe'l-Mohji of Soeltán-SerianLaga en als zijn zoons opgegeven: Tjakra-Negara (XIIa), Radèn Tjoelit (XIIb) en Kiai-Singa-Patih. Volgens eene aanteekening daarbij „regeerde XIIa en XIIb, beiden gedurende 30 jaar, deze onder den titel van Soeltán SeriMaharadja-Batoe of Soeltán Aboe'1-Rachman in de binnenlanden, gene onder den titel van Soeltán-Kiai-Gedeh te Tanah Pilèh [hoofdplaats Djambi]”, welke aanteekening, zooals wij hieronder zullen zien, niet geheel juist is, en ook niet klopt met de mede bij dien stamboom gevoegde „Ophelderingen en bijvoegingen", waarin o.a. vermeld wordt dat Raden-Tjoelit, ook Pangeran-Ratoe getiteld, bij Kiai-Singa-Patih's dood naar de benedenlanden kwam en naar Batavia verbannen werd (1710 of 1711)". [Van 1688 tot 1710 is slechts 22 jaar].

1) Voorkomende in het „Eerste deel der Brieven en Papieren uijtte respective gewesten van Indien tot Batavia overgebragt met de schepen Java den 8 Augustij in Tessel en Zuitbevelant voor de Vere gearriveert den 29 October." Elfde boek, C.C.C.C.C., 1689, Kol. Archief, No. 1342.

2) Register der generale Resolutien genomen bij de Hoge Regeringe van India in 't Casteel Batavia zedert primo Januarij tot Ult ${ }^{0}$ October 1688. Resolutie ddo. 19/4 - 1688, folio $221 ; 23 / 4-1688$, folio $224 ; 25 / 5-1688$, folio 268 ; 18/6-1688, folio 321 en 13/7-1688, folio 352. Kol. Archief, No. 603.

Realia. Register der generale Resolutiën van het Kasteel Batavia, 16321805. Uitgegeven door het Bat. Gen., 's-Gravenhage-Batavia, dl. II, 1885, vermeldt op p. 38 nog de resoluties: $13 / 6-1688$ en 19 en $23 / 10-1688$.

3) Zie o.a. Resolutie 2/9-1706 en 2/8-1707, Realia, II, p. 38.

D1. 83. 
pagnie te beoorlogen. Raden Tjoelit liet zich te Moeara Tĕbo tot Sultan van Mangoendjaja uitroepen en nam den titel aan van Sultan Sri Maharadja Batoe of Sultan Abdoe'l Rachman.

Tengevolge dezer binnenlandsche twisten leed het kantoor te Djambi zooveel nadeel, dat den 15den September 1690 besloten werd Djambi als zelfstandige post op te heffen, en te plaatsen onder het beheer van dat te Palembang.

In het „Register der generale Resolutien des Casteels Batavia genomen in Raden van India zedert primo Januarij tot ult ${ }^{0}$ december $\mathrm{A}^{0} 1690^{\prime}$, vinden wij op p. 420 onder 15 September 1690 aangeteekend :

„In stede van voormelte Sabelaer ${ }^{1}$ ) is geresolveert tot opperhooft over Palembang aen te stellen den pl. Coopman, en tegenwoordig hooft op Jamby, Sybrandt Swart, welcke laeste comptoir aen het eerste onderhorig wesen sal, en light door een vaendrig voor eerste, en soo lange daer ter plaetse niet of weijnig meer te verrigten valt, als onse besettinge in goede ordre te houden, konnen bedient, en waergenomen werden, hetwelck wij den voorn. Commissaris ${ }^{2}$ ) sullen aen bevelen, omme in der tijt te doen stant grijpen".

Djambi werd dus in 1690 door ons niet verlaten.

Anderhalve maand later, namelijk den 31sten October 1690, dus nog vóórdat deze reorganisatie haar beslag had gekregen, werd bovenbedoelde Sybrant Swart, Opperkoopman te Djambi, uit wraak voor een - ongetwijfeld nogal hardhandige - bestraffing door zijn huisjongen vermoord.

De wijze waarop zich dit heeft toegedragen vinden wij vermeld aan het slot van een zich in het Algemeen Rijks Archief te 's-Gravenhage bevindend schrijven, ddo. 6 November 1690, van Willem Sabelaar en Rippert Pelle, Kooplieden te Palembang, gericht aan de „Edele Erntfeste gestrenge Hoog.agtb. Manhafte welwijse, verresiende Seer genereuse en gants bescheydene Heere en Heeren Aande Hoog Edele Heer Joannes Camphuys gouverneur generaal ende Edele Heeren Raeden van nederlants India”.

Het desbetreffend gedeelte uit dien brief luidt aldus :

1) Willem Sabelaar was Resident van Palembang.

2) Deze Commissaris was Isaacq van Thijen. Zie o.a. p. 37-48, brief ddo. 31/12-1690, Kol. Archief, E.E.E.E.E., No. 22. 
„Edele Hoog agtb. Heeren.

Naar 't sluijten deses laat deese Hoogheijt ons toekomen een brieff gesz. door den Raat in Jambij gedateert $\mathrm{P}^{\mathrm{mo}}$ courant behelsende ten principale dat $\mathrm{S}^{r}$ Sijbrant Swart hebbende ruijm twee maanden Seer krank geweest en eeniger maeten gereconvalesceert, sijnde daags te vooren een sijn 'ex lijff eijgen Jongen over desselfs quaat comportement, binnen Sijn wooning hadt laten straffen, dat voorsz. jongen, met een geswinde sprong, hoewel hij inde ketting geclonken was, Sig meester van een kris, die inde kamer op een stoel lag, gemaakt, en daar meede Sijn meester die hem niet konde ontvlugten, vier wonden in het lighaam gestooken hadt, waar van gedagte Sijn Edele een weijnig daar aan overleden was, 't geent Soo onder de Jambineesen als onder de onse groote alteratie veroorzaakt hadde" ${ }^{1}$ ).

Denkelijk zal het overlijden van den Opperkoopman S. Swart aanleiding hebben gegeven de inkrimping van het kantoor te Djambi te bespoedigen, want na dien worden alle zaken van Djambi door de Residenten van Palembang naar Batavia gemeld.

In de resolutie boeken over de volgende jaren vinden wij nog enkele besluiten Djambi betreffende, waarvan wij alleen aanhalen die van 14 Juli 1702, waarbij een soort instructie voor den te Djambi posthoudenden ",Sergeant” werd vastgesteld ${ }^{2}$ ).

De vaandrigs of sergeanten, die de O. I. C. te Djambi vertegenwoordigden, bleven zich „Resident” noemen, en maakten ook aanspraak op de aan die betrekking verbonden inkomsten, hetgeen blijkt uit een brief van 18 Maart 1706 van de Kooplieden te Palembang, P. Jn. Aouwer en R. Leers, gericht aan den Gouverneur Generaal Joan van Hoorn en de Edele Heere Raden van N.-I., waarin o.a. de aanteekening voorkomt, dat Pieter Wendels van Amsterdam, ,Corperaal der Inf $^{r i e}$. tot Resident van Jamby aangesteld", verzoekt als zoodanig , gehonoreerd te werden, winnende hij alsnu f $16 .{ }^{\prime 3}$ ).

In 1706 werd de Commissaris P. Rooselaar - Oud-Gouverneur en Directeur der Molukken, later Gouverneur van Malacca - naar Djambi gezonden, met opdracht na te gaan of er aanleiding bestond Djambi weder van Palembang af te scheiden, en tot zelfstandig

1) Kol. Archief, No. 1375, IIe deel, 22e boek, E.E.E.E.E., 1690, folio 35 .

2) Realia, II, p. 38 .

3) Kol. Archief W.W.W.W.W., 1707, p. 21. 
kantoor te verheffen, zoomede om een nieuw contract met Kijaj Gedée aan te gaan.

Naar aanleiding van de door hem uitgebrachte rapporten, werd eerst bij resolutie van 28 Juni $1707^{1}$ ) bepaald, dat er een Onder Coopman of Boekhouder als Resident derwaarts gezonden zou worden, en vervolgens bij resolutie van 7 Juli daar aan volgende ${ }^{2}$ ), dat Djambi weer ,een comptoir op zich zelfs en van Palembang gescheijden" zou worden.

De motieven, die tot het laatstbedoeld besluit hebben geleid zijn neergelegd in een brief van 9 November 1707 naar Patria ${ }^{3}$ ):

„Engelijk Nahier in 't vervalle rijck van Jambij nu al eenige Jaeren tusschen de princen en gebroeders Kieij geddee en Pringabaija in een groote duijsterheijt en verwarringe hebben gefluctueerd en den gedeligueerden Malac. gouverneur Rooselaar door kortheijt des tijds in 't lest des voorgaande Jaars niet veel omtrent deselve hadde konne verrigte soo hebben wij mits de voorgevalle veranderingen der Engelsen tot Banjer van te meer consideratie geagt te wesen dat peperrijck niet langer alleen door een magt van een sergeant en eenige Inlandse militairen onder opsigt van die van Palembang te laten, maar weder eene residentie als van outs op sig selven te begrijpen, waar toe den 12 Augusteij over Palembang derwaarts is geschikt Abraham Patras" ${ }^{4}$ ).

A. Patras, die den 26sten September 1707 te Djambi arriveerde ${ }^{5}$ ), zond spoedig na aankomst den Corporaal Willem de la Garde, van Amsterdam, met een brief van den Gouverneur Generaal naar Pangeran Pringabaja van Mangoendjaja te Moeara Tĕbo, met de bedoeling hem te bewegen naar Djambi af te komen, en zich weder met zijn broeder Kijaj Gedée en de O. I. C. te verzoenen ${ }^{6}$ ).

Deze poging had echter geen succes, waarop hij in 1710 werd gevangen genomen en ingevolge de resolutie van 26 September van

1) Register der generale Resolutiën, enz. van 1/1-30/9-1707, folio 918 .

2) Idem, folio 939 .

3) Eerste deel der Brieven en Papieren van Batavia overgekomen, I, X.X.X.X.X., 1708, folio 18-19. Kol. Archief, No. 1626.

4) Eene levensbeschrijving van A. Patras met portret komt o.a. voor in „De Indische Verlofganger”, 4e Jrg., No. 43, 1926, p. 505-507, S. Kalff „Abraham Patras”.

5) Tweede deel der Bataviasche Inkomende Brieven overgekomen, X.X.X.X.X., 1708, No. 9, Kol. Archief, No. 1635.

5) Idem „Pangirang Pringabaja” noemde zich volgens een bijlage van dien brief ook „Sery Maha radja batoe djoehan Paralawan alamisjah”. 
dat jaar ,gedetroneert en desselfs oudste broeder Sulthan Kiaij Gedee tot Koning van Jamby verkozen" ${ }^{1}$ ).

In het daarop volgende jaar werd Pangeran Pringabaja met een gevolg van „99 coppen”, -als een krijgsgevangene, eerst naar het eiland Edam, later naar Banda verbannen ${ }^{2}$ ).

Met deze opsomming van feiten zou gevoegelijk dit tijdsbestek der geschiedenis van Djambi kunnen worden besloten, want wij hebben het jaar 1707 reeds overschreden, maar, nu de gelegenheid zich daartoe tóch voordoet, lijkt het gewenscht hierbij nog even aan te teekenen, dat wij Djambi in 1724 niet hebben verlaten ${ }^{3}$ ), maar er - met eene onderbreking van $1754-1756^{4}$ ) en van $\left.1759-1760^{5}\right)$ nog ruim veertig jaren zijn verbleven.

Onder den Opper Koopman Simon Hommelberg werd het fort te Djambi - dat zij n.b. pas hadden verbouwd ${ }^{6}$ ) — den 20sten Maart 1768 des morgens om ongeveer 6 uur onverwachts door de Djambiërs aangevallen. Na eene heldhaftige verdediging was de bezetting door uitputting en groot verlies van manschappen ten slotte verplicht zich in te schepen en Djambi te verlaten ${ }^{7}$ ).

Bij resolutie van 10 Mei 1768 werd den Advocaat-fiscaal Mr. Wouter Rudolph van Senden opgedragen onderzoek te doen ,naar de primitieve oorzaak van de attaque en alle de omstandigheden van de overrompeling van het Fort aldaar" ${ }^{8}$ ). Deze bracht een uitvoerig rapport uit, hetwelk in zijn geheel werd opgenomen in de resolutie van 22 Juni d.a.v. $\left.{ }^{9}\right)$. De Gouverneur Generaal en de Raad vereenigden zich met de conclusies van den Advocaat-fiscaal, welke luidden:

1) Register Resolutiën, 1/1-Ult ${ }^{0}$ Octr. 1710, Resolutie 26 September 1710, folio $633-636$.

2) Idem, 1/1-Ult ${ }^{0}$ October 1711, Resolutie 6 Januari 1711.

3) Wijl Valentijn in zijn - bereids aangehaald - werk geen namen van kooplieden te Djambi nà 1724 vermeldde, meende Prof. Veth te mogen concludeeren, dat wij in dàt jaar Djambi voor goed verlieten. Z.H.Gel. vergat blijkbaar, dat Valentijn's boek in 1726 verscheen.

4) Resolutie 7 Maart 1754 en 25 Juni 1756, Realia, II, p. 39. Zie ook N. Mac-Leod, ,Uit de geschiedenis der Oost-Indische Compagnie in de tweede helft der 18e eeuw", I, Gids, 32e Jrg., I, 1910, p. 766-767.

5) Resolutie 27 Juli 1759, 15 April en 7 November 1760, Realia, II, p. 39 en 40. Mac-Leod, idem.

6) Brieven van den Opperkoopman A. F. van Solms te Djambi naar Batavia, ddo. 9/6-ell 30/9-1765, en van zijn opvolger Simon Hommelberg, ddo. 15/51766. Kol. Archief, No. 3074.

7) Register Resoluties jaar 1768, Kol. Archief No. 698, Resolutie 10 Mei 1768 , p. $351-354$. Zie ook Realia, II, p. 40.

8) Idem.

9) Idem, Resolutie 22 Juni 1768 , p. 575-583. 
dat de Resident van Djambi het contract wel streng, maar rechtvaardig had nageleefd, waardoor verbittering was ontstaan, maar dat verder noch hem, noch de bezetting iets ten laste kon worden gelegd. Allen werden daarop uit het voorarrest, waarin zij sedert hun aankomst te Batavia waren gesteld, ontslagen, de ingehouden gage uitbetaald, en bovendien een douceur toegekend gelijk staande met de ingehouden gage ${ }^{1}$ ).

$\mathrm{Na}$ deze overrompeling, die der Compagnie op een bedrag van f 116241 . - was komen te staan ${ }^{2}$ ), achtte zij het blijkbaar beter het rijk van Djambi verder maar aan zijn lot over te laten.

En thans de loge in 1707 (afbeelding 1).

Zij was met het front naar de rivier gekeerd, en bestond uit : ,een loose bamboese pagger, welcke ook op bijde zijde liep, agter open" (de letters Q), eene aarden omwalling en de eigenlijke „,gedoeng”.

Volgens de op de teekeningen voorkomende verklaringen, stond ,dese bamboese pagger met hoogh water soo nuw en dan 1 a 2 voet in 't water en in de drooge tijt wel ruijm een musquet schoot ${ }^{3}$ ) van 't water aff". Vóórin, ongeveer in het midden, bevond zich de hoofdingang, waarboven ,een kamertje met pannen gedeckt” op stijlen, dat dienst deed als observatiepost (afbeelding 2).

Binnen deze eerste omheining lag de eigenlijke versterking, lang ongeveer 75 en breed 38 meter, bestaande uit een niet geheel regelmatig vierkanten aarden omwalling, besloten tusschen twee ,palensaden" (K.L.M.2.i.N.Q.Z.G.H.X. en I.), breed plus minus twee, en hoog 4 meter. $\mathrm{Zij}$ bezat twee ingangen, de hoofdpoort, gericht naar de rivierzijde (afbeelding 1, cijfer I.) en ten Oosten daarvan nog een „loose” poort (afbeelding 1,Z.Q.).

Het grootste gedeelte der ruimte binnen deze omwalling werd ingenomen door het woon- tevens pakhuis, lang en breed ongeveer $50 \mathrm{bij}$ 20 meter. Volgens de eene teekening (afbeelding 1) had dit gebouw den vorm van een trapezium, volgens de andere (afbeelding 3 ) van

1) Idem noot 7 , vorige pagina, p. 583-586.

2) Idem, Resolutie 16/9-1768. Zie ook Realia, II, p. 40.

3) Volgens mondelinge mededeeling van den Heer L. N. Cazaux van Staphorst, gep. Kol. Korps Mariniers, werkzaam bij de Krijgsgeschiedkundige Afdeeling van den Generalen Staf te 's-Gravenhage, die zoo behulpzaam was hiernaar een speciaal onderzoek in te stellen, moet een musket destijds ongeveer $125 \mathrm{M}$. hebben gedragen. De loge te Djambi zal dus op $\pm 125 \mathrm{M}$. van de rivier hebben gelegen. 
een vierkant. De totale hoogte van den grond tot den nok van het dak bedroeg 14,30 meter.

Het was gedeeltelijk van steen (op de teekening - afbeelding 4 geel gekleurd), gedeeltelijk van hout (grijs en groen gekleurd) opgetrokken, en met pannen gedekt (rood gekleurd). De metselsteenen onderbouw reikte tot 2.50 meter boven den grond.

De geheele benedenverdieping werd voor opslagplaats gebruikt.

Door middel van een houten trap aan de voor-, en een aan de achterzijde bereikte men de woonruimte, waarvan nog een gedeelte eveneens voor pakhuis was ingericht (afbeelding 1, de letters R.). De Koopman bewoonde op die eerste verdieping drie aan de Oostzijde gelegen kamers (afbeelding 1, Nos. 1), waaraan het kantoor (afbeelding 1, No. 6) aansloot Die kamer - naar de rivierzijde gericht was door een deur (3. Alle deuren werden met een 3 aangegeven) verbonden met een gang (afbeelding 1, No. 2), waarin een wenteltrap, die naar een opkamertje leidde.

Voor den Sergeant waren twee kamers aan de Westzijde van het gebouw ingeruimd (afbeelding 1, Nos. 4), terwijl de vijf aan de achterzijde gelegen kamers (afbeelding 1, Nos. 5), waarlangs een ,galderijtje" liep, voor de overige bewoners waren bestemd.

De kamers op de afbeelding 1 met een $Z$. aangegeven, waren voor „de wacht der soldaaten, off corps du guarde”.

De bezetting bestond toen ter tijde namelijk uit ${ }^{\mathbf{1}}$ ):

11 Europeanen, te weten: „1 ondercoopman en hooft

$$
\begin{aligned}
& 1 \text { sergaent } \\
& 1 \text { pl. assistent } \\
& 3 \text { corporaals } \\
& 5 \text { schildergasten". } \\
& \text { Totaal . . . . } 11 \text {,coppen”, en }
\end{aligned}
$$

12 ,Bouginezen” waarvan : „1 corporaal

$$
11 \text { gemeen" }
$$$$
\text { Totaal . . . . } 12 \text {,coppen”, }
$$

dus in totaal 23 ,coppen”, benevens „2 Comps. Lijfeijgene”, ook Boegineezen, wier hoofden ergo niet als ,coppen” medetelden.

Waar die loge ergens ter hoofdplaats gelegen was, is nog een open

1) Brief van A. Patras naar Batavia, Tweede deel der Bataviasche Inkomende Brieven overgekomen X.X.X.X.X. 1708, No. 9, Kol. Archief, No. 1635. 
vraag. Moeten wij de, zich eveneens in het Algemeen Rijks Archief te 's-Gravenhage aanwezige, kaart ,van de Rivier van Jamby, van de mond tot aan Jambij, schaal van 5 Duitsche mijlen $=125$ ", dateerende uit de $17 \mathrm{e}$ eeuw, gelooven, dan stond - gelijk uit bijgaande reproductie van die kaart blijkt - zoowel de Engelsche- als de Hollandsche loge destijds aan den linkeroever van de rivier, dus in of nabij de doesoen Petjinäan ${ }^{1}$ ).

Aannemende, dat deze kaart de situatie in de $17 \mathrm{e}$ eeuw juist wedergeeft, dan moet de loge sedert 1615 naar de overzijde van de rivier zijn verplaatst, want naar alle waarschijnlijkheid lag onze eerste vestiging aan den rechteroever ${ }^{2}$ ).

Onmogelijk is dit niet, aangezien zij in dit tijdsverloop eene geheele geschiedenis had doorgemaakt.

Zoo werd zij in het jaar 1617 bij een inval van de Portugeezen in Djambi door het vuur verwoest ${ }^{3}$ ). Hetzelfde gebeurde nog eens in $1636^{4}$ ), en hoewel er in dat jaar weer een nieuwe werd gebouwd ${ }^{5}$ ),

1) Het is wel eigenaardig, dat hier juist de minder goed bevaarbare Koeala Bĕrbah werd geteekend, terwijl het toch reeds in 1615 gebleken was, dat de Koeala Nioer voor de scheepvaart verreweg te prefereeren viel. Zie J. W. J. Wellan, „Onze eerste vestiging in Djambi” in Bijdr. Kon. Inst., dl. 82, Afl. III en IV, 1926, p. 344, noot 1 en pag. 345.

Hieronder volgt de verklaring van eenige op die kaart voorkomende namen: ,Musquite gat $=$ Soengei Sadoe; Ajer itam $=$ soengei Ajer Itam Dalem; Qualeschoor = Koeala Nioer; Jebas = Djěboes; R. Compo en Compeschoor $=$ de rivier Kompeh en het dorp van dien naam; Londran = de doesoen Londrang; R. Tornan = Soengei Tomian; Langar = de doesoen Langgar ; Roucano $==$ de doesoen Roekam; Combon $=$ Sěkombang; Songi Bonto = Soengei Boengin: Pambailamma = Djambi Lama; Out Suchedana = Soekadana Lama; Nieu Suchedan = Soekadana Baroe; Tallam douckoi = Talang Doekoe; Moori Compe ${ }^{\prime}=$ Moeara Kompeh; Patterijen, mogelijk: potterijen, steenbakkerijen, ook mogelijk : batterijen; Jamby $=$ Djambi, hoofdplaats ; Passeban $=$ de raads- of vergaderzaal $;$ Desapijn $=$ Danaw Sipin $;$ Canali $=$ Danaw Kĕnali.

De gegevens dezer kaart geven aanleiding de aanteekeningen van de in het Tijdschrift Kon. Ned. Aardr. Genootschap, 2e Ser., dl. XLII, Afl. 6, op p. 851 voorkomende calque van een kaart dateerende uit 1753 als volgt te verbeteren:

[S. Nioer] moet worden: [Batang Hari] ; a. het watertje Sapyn = Danaw Sipin; b. Hollandse logie Palijn $=$ Hollandsche loge te Djambi; c. Nieuw Sucheran $=$ Soekadana Baroe: d. Jammelemme $=$ Djambi Lama; e. Oud Sucheram = Soekadana Lama ; f. Combon = Sĕkombang $;$ h. R. Ramboelan = Rimboe Lama; i. Londean = Londrang; Compeschoor $=$ Moeara Koempih Ilir.

2) „Onze eerste vestiging in Djambi”, zie ${ }^{1}$ ) hierboven, p. 356-358.

${ }^{3}$ ) Prof. Dr. H. T. Colenbrander, „Jan Pietersz. Coen. Bescheiden omtrent zijn bedrijf in Indië', II, 's-Gravenhage, 1920, p. 307.

4) Dagh-Register 5 Januari 1636, p. 6-7.

5) Idem, 16 Maart 1636, p. 43-44. 
zal dit wel een tijdelijke zijn geweest, want bij resolutie van $19 \mathrm{Fe}-$ bruari $1638^{1}$ ) werd de „Oppercoopman De Vogel geautoriseerd aldaar een nieuwe loge te maken". In 1643 onderging de loge eene verbouwing ${ }^{2}$ ): ,,de Chinese winckels binnen de logie staende” werden namelijk ,aen de straet geopend”, waardoor ,oock het pericul wierd voorgecomen van in de logie bij toeloop van Javanen ende andere overvallen te worde". In $1663^{3}$ ) werden er met den Vorst van Djambi onderhandelingen geopend over de plaats voor een nieuw etablissement aldaar. De resultaten daarvan zijn niet bekend. Blijkens mededeelingen van den Koopman te Djambi van het jaar $1668^{4}$ ), ,hadde 's Comp'. logie groot perical gelopen van door eenige booswichten in de assche te sullen zijn gelegt”, terwijl in $1675^{5}$ ), ,,verscheijde dier fielten [d.w.z. Djambiers] selfs Comps. logie by nagt en ontijden veel malen hadden begooyt en aangerant". Vier jaar later werd Djambi aangevallen door Djohor, en eenige Makassaarsche legerbenden. De post werd toen verlaten en in 1680 weer in bezit genomen. Bij terugkeer bleek de loge niet veel geleden te hebben ${ }^{6}$ ).

Ziedaar hetgeen tot dusver over onze nederzetting te Djambi gepubliceerd is.

Zoolang wij daaromtrent geen zekerheid hebben, zal dus moeten worden aangenomen, dat de in 1663 met den Vorst van Djambi gevoerde onderhandelingen over het bouwen van eene nieuwe nederzetting succes hebben gehad, en omstreeks dien tijd de loge werd gebouwd, die zich daar in 1707 nog bevond, en waarvan de teekeningen hierbij zijn weergegeven.

Deze onderstelling gaat alleen dàn op, als er goede materialen voor gebruikt zijn, want die houden het wel een veertig jaren uit, maar daarna zijn ze ook op. Dit klopt nu wonderwel met de bevindingen van A. Patras, die in zijn eersten brief naar Batavia, gedateerd 30 October $1707^{7}$ ) al klaagt, dat hij zijn Boegineesche soldaten moet gebruiken voor het opknappen van de loge, ,,vermits den ten eene maal bouwvallige staat en daarom sijnde bepaggering”.

1) Realia, II, p. 37.

2) Dagh-Register, 11 Januari 1643, p. 10-11.

3) !dem, 5 Februari 1663 , p. 30.

4) Idem, 27 Mei 1668, p. 161.

5) Idem, 26 Juni 1575 , p. 172.

6) Jdem, 20 September 1679, p. 427 en 429, en 22 Mei 1680, p. 280, 387, 545, 546 eti 646.

$\left.{ }^{7}\right)$ Tweede deel der Bataviasche Inkomende brieven overgekomen X.X.X.X.X., 1708, No. 9, Kol. Archief, No. 1635. 
Vermoedelijk heeft hij, om zijn betoog meer kracht bij te zetten, de hierboven toegelichte teekeningen laten vervaardigen en naar Batavia opgezonden, want bij resolutie van 15 Juni $1708^{1}$ ) werd besloten te Djambi wederom eene nieuwe loge te doen bouwen.

1) Register Resoluties van 1 Januarij tot $\mathrm{Ult}^{0}$ October 1708. 